IRA-International Journal of Education \& Multidisciplinary Studies

ISSN 2455-2526; Vol.03, Issue 03 (2016)

Institute of Research Advances

http://research-advances.org/index.php/IJEMS

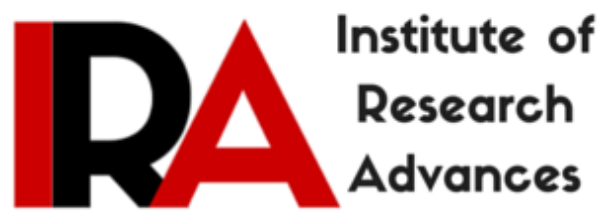

\title{
A study on the difference of attitude towards the acceptance level of Continuous and Comprehensive Evaluation (CCE) System among the eighth grade students of Hooghly District in West Bengal
}

\author{
${ }^{1}$ Dr. Saugata Basu \& ${ }^{2}$ Dr. Debabrata Debnath \\ ${ }^{1}$ Department of Biology, Uttarpara Govt. High School, Uttarpara, \\ Hooghly - 712258, West Bengal, India. \\ ${ }^{2}$ Department of Education, University of Gour Banga NH - 34, \\ P.O. Mokdumpur, Dist. Malda, PIN - 732 103, West Bengal, India.
}

DOI: http://dx.doi.org/10.21013/jems.v3.n3.p17

\section{How to cite this paper:}

Basu, S., \& Debnath, D. (2016). A study on the difference of attitude towards the acceptance level of Continuous and Comprehensive Evaluation (CCE) System among the eighth grade students of Hooghly District in West Bengal. IRA International Journal of Education and Multidisciplinary Studies (ISSN 24552526), 3(3). doi:http://dx.doi.org/10.21013/jems.v3.n3.p17

(C) Institute of Research Advances

(c) EY-NC

This works is licensed under a Creative Commons Attribution-Non Commercial 4.0 International License subject to proper citation to the publication source of the work.

Disclaimer: The scholarly papers as reviewed and published by the Institute of Research Advances (IRA) are the views and opinions of their respective authors and are not the views or opinions of the IRA. The IRA disclaims of any harm or loss caused due to the published content to any party. 


ABSTRACT
The National Policy of Education (1986) had emphasized upon continuous and
comprehensive evaluation (CCE) for the improvement of the quality of school
education [1]. Continuous and comprehensive evaluation is an education system newly
introduced by the West Bengal Board of Secondary Education (WBBSE) [2]. It
emphasizes two fold objectives - Continuity in evaluation and assessment of broad
based learning. The present investigation was taken to study the difference of attitude
towards the acceptance level of continuous and comprehensive evaluation (CCE)
system among the students of three randomly selected schools of Hooghly District of
West Bengal. The investigators prepared standardized questionnaires for the purpose
of the present dissertation. The students' attitude, reflected in the questionnaire, was
analysed statistically with IBM SPSS Statistics Version 20.0.

\section{Key Words:}

Attitude, Acceptance level, Continuous and comprehensive evaluation system, CCE, WBBSE, Hooghly District, West Bengal.

\section{INTRODUCTION}

West Bengal Board of Secondary Education (WBBSE) has introduced Continuous and Comprehensive Evaluation (CCE) system from the academic year 2007-08. But from the very next academic year, i.e., 2008-09 the format of CCE system has been changed by WBBSE where from Class V onwards (up to Class X), all Government, Government-sponsored and Government-aided schools have to conduct 5 Unit Tests along with 2 Remedial Tests in an academic year followed by a Summative Evaluation/Annual Examination [2].

For the students of Class I to Class VIII, the WBBSE has introduced revised Continuous and Comprehensive Evaluation (CCE) system from the academic year 2013. Two types of assessment referred to in this CCE system are Formative and Summative. The periodicity of both types of assessment are thrice (i.e., $1^{\text {st }}, 2^{\text {nd }} \& 3^{\text {rd }}$ Formative \& Summative Evaluations) in an academic year. Although, in case of class IX \& X the earlier system of CCE (which was introduced from the academic year 2008-09) and annual academic calendar was followed [3].

The WBBSE has implemented the revised system of CCE - 2013 for the students of Class IX from the academic year 2015 and the same for the students of Class X from the present academic year 2016 [3].

In the present system of CCE weightage percentage varies from $15 \%$ to $38 \%$ for Formative Assessment and $62 \%$ to $85 \%$ for the Summative Assessment in different classes from $\mathrm{V}$ to $\mathrm{X}$. The WBBSE mentioned Five indicators for Formative Assessment, viz., Participation, Questioning and Experimentation, Interpretation and Application, Empathy and Co-operation, Aesthetic and Creative Expression. In the Summative Assessment, according to WBBSE, one-third of the question would be Open-ended and others would judge the Analytic Power and Creativity of the students. There would be Four point Grading system for the Formative and Seven point grading System along with Marks for Summative Assessment in the present CCE system. 
This study is an effort to find out the attitude towards the acceptance level of CCE of the students of eighth grade stage of Hooghly District in West Bengal.

\section{OBJECTIVES OF THE STUDY}

1) To study the Attitude towards the acceptance level of CCE for the sample under consideration.

2) To compare the Attitude towards the acceptance level of CCE for their strata and gender.

\section{HYPOTHESES OF THE STUDY}

0H 1 : There is no significant difference in the attitude towards the acceptance level of CCE between the male and female students.

0H 2 : There is no significant difference in the attitude towards the acceptance level of CCE between the urban and rural students

0H 3 : There is no significant difference in the attitude towards the acceptance level of CCE between the urban male and urban female students.

0H 4 : There is no significant difference in the attitude towards the acceptance level of CCE between the rural male and rural female students.

0H 5 : There is no significant difference in the attitude towards the acceptance level of CCE between the urban male and rural male students.

0H 6 : There is no significant difference in the attitude towards the acceptance level of CCE between the urban female and rural female students.

\section{RESEARCH METHODOLOGY}

\section{Sample}

Two hundred students - one hundred male and one hundred female students of class VIII were selected randomly from the Hooghly District of West Bengal for the study.

\section{Area of Study}

The schools were selected randomly from urban and rural areas in the Srerampore SubDivision of the Hooghly District of West Bengal.

\section{Number of Schools}

Three schools - two from urban and one from rural situated in Srerampore SubDivision, Hooghly District, West Bengal were selected randomly for the study.

\section{Gender}

Out of 200 randomly selected eighth grade students, 100 were male and 100 were female students. 


\section{Strata}

The questionnaire was administered on 200 randomly selected eighth grade students among which, 100 were male and 100 were female students.

\section{Variables}

In the present study, total three variables were considered by the researcher, viz.,

\section{Dependent Variable}

\section{Attitude towards the acceptance level of CCE}

By this terminology it is meant the attitude towards the acceptance level of CCE, expressed by the students considered as Sample.

\section{Independent Variables}

\section{Gender}

It is the gender of the student individuals selected for the study.

\section{Strata}

Strata refers the Urban and Rural area of study.

\section{Tools used}

Questionnaire to study the attitude towards the acceptance level of Continuous and Comprehensive Evaluation (CCE) system among the randomly selected eighth grade students was developed and standardized by the researcher.

\section{Method}

Survey Method was used to collect data and IBM SPSS Statistics Version 20.0 was used for statistical interpretation of data under the present study.

\section{Sampling}

A sample of two hundred students was selected randomly from class VIII of three Higher Secondary Schools considering both genders and strata. The sample consisted of one hundred male and one hundred female students. Out of 100 male students, 50 were urban and 50 rural and out of 100 female students 50 were urban and 50 rural. 


\section{Sampling Chart}

\begin{tabular}{|c|c|c|c|c|}
\hline Area & Name of the School & $\begin{array}{c}\text { Male } \\
\text { Students }\end{array}$ & $\begin{array}{l}\text { Female } \\
\text { Students }\end{array}$ & \begin{tabular}{|l} 
Total \\
\end{tabular} \\
\hline \multirow[t]{2}{*}{ Urban } & $\begin{array}{l}\text { Uttarpara Govt. High } \\
\text { School }\end{array}$ & 50 & - & \\
\hline & $\begin{array}{l}\text { Uttarpara Girls'. High } \\
\text { School }\end{array}$ & - & 50 & \\
\hline Total & & & & 100 \\
\hline Rural & $\begin{array}{c}\text { Bamunari High School } \\
\text { (H.S.) }\end{array}$ & 50 & 50 & 100 \\
\hline TOTAL & No. of School : Three & 100 & 100 & 200 \\
\hline
\end{tabular}

\section{Construction of Questionnaire}

The Questionnaire to study the Attitude towards the acceptance level of Continuous and Comprehensive Evaluation (CCE) system contained 50 statements / items. These statements / items have covered the following important and basic dimensions :
A) School Activity (Dimension :1)
B) Future Prospect (Dimension : 2)
C) Home Atmosphere (Dimension : 3)
D) Teachers' Participation (Dimension : 4)
E) Students' Satisfaction (Dimension : 5)

There were ten statements / items in each of the dimensions mentioned above. Thus altogether there were 50 statements / items in a set of which 49 had positive and one had negative statements. Each statement has to be rated by the individual student on a Likert type 5-point scale in a continuum from Strongly Agree to Strongly Disagree. 


\section{RESULT AND DISCUSSION}

Descriptive analysis (Mean, Standard Deviation and Standard Error of Mean) of the Attitude towards the acceptance level of Continuous and Comprehensive Evaluation (CCE) were calculated separately for male and female students of urban and rural area and presented in the TABLE : 1 .

From the result of the descriptive analysis (Table : 1) it is seen that Male students have shown better attitude towards the acceptance level of CCE in comparison to the Female students and Urban students have shown better attitude towards the acceptance level of CCE in comparison to the Rural students.

To see whether the mean difference is significant or not Paired Sample t-Test was applied and the result is given in the TABLE $: 2$

From the result of the Paired Sample t-Test of the Attitude towards the Acceptance Level of CCE system between the Male and Female students of Urban and Rural area, it is seen that the t-value is not significant at the 0.05 level for Male \& Female students Pair, Urban Male \& Urban Female students Pair, Rural Male \& Rural Female students Pair and Urban Female \& Rural Female students Pair. So the null hypotheses $0 \mathrm{H} \mathrm{1,0H}$ $3,0 \mathrm{H} 4$ and $\mathrm{OH} 6$ are retained. Hence, there are no significant differences in the Attitude towards the Acceptance Level of CCE system between the Male \& Female students, Urban Male \& Urban Female students, Rural Male \& Rural Female students and Urban Female \& Rural Female students.

But the t-value is significant at the 0.05 level for Urban \& Rural students pair and Urban Male \& Rural Male students pair. So $0 \mathrm{H} 2$ and $0 \mathrm{H} 5$ null hypotheses are rejected. Therefore, statistical analysis shows that there are significant differences in the Attitude towards the Acceptance Level of CCE system between Urban \& Rural students and Urban Male \& Rural Male students.

\section{CONCLUSION}

It was found through statistical analysis that Urban students have shown better attitude towards the acceptance level of CCE system in comparison to the rural students. It was also found that and Urban male students have shown better attitude towards the acceptance level of CCE system in comparison to the rural male students.

In western countries a very few research work with CCE has been made to see the attitude of the students towards the system, but the amount of research work done in India, especially with students of West Bengal is almost nil. Since the education scenario of our country is totally different from that of the western country, the results of investigations with western students may not be true with Indian and more specifically for the students of West Bengal. Hence investigations, such as this, will be of much importance to all concerned. Moreover as the CCE system has newly introduced, the result of this dissertation will provide some valuable information not only for the future researcher, but also for the academic personnel related to secondary education system of West Bengal. 


\section{ACKNOWLEDGMENT}

The senior author is thankful to the Director of School Education (Secondary Branch), Govt. of West Bengal and the Headmaster, Uttarpara Govt. High School for giving permission to continue the research work. Sincere thanks and regards to Dr. Ujjwal Kumar Halder, Assistant Professor, Department of Education, University of Gour Banga for his valuable suggestions during the statistical analysis of this dissertation.

Thanks are also due to the respondent students for their helpful and active cooperation during the collection of data.

\section{References}

[1] Government of India, "National Policy on Education, MHRD, Department of Education, New Delhi” (1986).

[2] Continuous and Comprehensive Evaluation (CCE) - published by the West Bengal Board of Secondary Education (WBBSE) - 2013

[3] Basu, S., \& Debnath, D. (2016). A survey on continuous and comprehensive evaluation system introduced by West Bengal Board of Secondary Education among the students, teachers, guardians of Hooghly District of West Bengal. International Journal of Informative \& Futuristic Research, 3 (8), 3158-3166. 


\section{(Tables \& Figures)}

TABLE : 1

Showing the Descriptive analysis (Mean, Standard Deviation and Standard Error of Mean) of the Attitude towards the acceptance level of Continuous and Comprehensive Evaluation (CCE) for male and female students of urban and rural area

\begin{tabular}{|c|c|c|c|c|c|}
\hline Gender of & Area & $\begin{array}{c}\mathbf{N} \\
\text { Deviation }\end{array}$ & $\begin{array}{c}\text { Mean } \\
\text { Error of Mean } \\
\end{array}$ & Standard & Standard Students \\
\hline Male & Urban \& Rural & 100 & 181.35 & 23.73 & 2.37 \\
\hline Female & Urban \& Rural & 100 & 178.91 & 20.77 & 2.07 \\
\hline Male & Urban & 50 & 186.76 & 24.53 & 3.47 \\
\hline Female & Urban & 50 & 182.92 & 22.11 & 3.13 \\
\hline Male & Rural & 50 & 175.94 & 21.80 & 3.08 \\
\hline Female & Rural & 50 & 174.90 & 18.71 & 2.65 \\
\hline
\end{tabular}


TABLE : 2

Showing the distribution of Paired Differences with respect to Mean, Standard Deviation (SD), Standard Error of Mean (SEM) and ' $t$ ' value of the Attitude towards the Acceptance Level of CCE between the Male and Female Students of Urban and Rural area

\begin{tabular}{|l|l|l|l|l|l|l|}
\hline \multirow{2}{*}{ Pair } & \multicolumn{2}{|c|}{ Paired Differences } & \multirow{2}{*}{ t } & df & \multicolumn{2}{|l|}{$\begin{array}{l}\text { Sig. (2- } \\
\text { tailed) }\end{array}$} \\
\cline { 2 - 9 } & Mean & SD & SEM & & & \\
\hline Male - Female students & 2.44 & 30.50 & 3.05 & .800 & 99 & .426 \\
\hline Urban - Rural students & 9.42 & 30.82 & 3.08 & 3.056 & 99 & .003 \\
\hline Urban Male - Urban Female students & 3.84 & 32.39 & 4.58 & .838 & 49 & .406 \\
\hline Rural Male - Rural Female students & 1.04 & 28.75 & 4.07 & .256 & 49 & .799 \\
\hline Urban Male - Rural Male students & 10.82 & 32.19 & 4.55 & 2.38 & 49 & .021 \\
\hline Urban Female - Rural Female students & 8.02 & 29.65 & 4.19 & 1.91 & 49 & .062 \\
\hline
\end{tabular}




\section{(Data \& Statistics)}

TABLE-1

Paired Samples Statistics

\begin{tabular}{|ll|r|r|r|r|}
\hline & & Mean & $\mathrm{N}$ & Std. Deviation & $\begin{array}{c}\text { Std. Error } \\
\text { Mean }\end{array}$ \\
\hline \multirow{2}{*}{ Pair 1 } & MALE, urban \& rural & 181.3500 & 100 & 23.72374 & 2.37237 \\
& FEMALE, urban \& rural & 178.9100 & 100 & 20.77104 & 2.07710 \\
Pair 2 & Urban Male \& Female & 184.8400 & 100 & 23.31459 & 2.33146 \\
& Rural Male \& Female & 175.4200 & 100 & 20.22059 & 2.02206 \\
Pair 3 & MALE, urban, UGHS & 186.7600 & 50 & 24.53033 & 3.46911 \\
& FEMALE, urban, Town & 182.9200 & 50 & 22.11274 & 3.12721 \\
& MALE, rural, Bamunari & 175.9400 & 50 & 21.80939 & 3.08431 \\
Pair 4 & FEMALE, rural, & 174.9000 & 50 & 18.70529 & 2.64533 \\
& Bamunari & & 50 & 24.53033 & 3.46911 \\
Pair 5 & MALE, urban, UGHS & 186.7600 & 50 & 21.80939 & 3.08431 \\
& MALE, rural, Bamunari & 175.9400 & 50 & 22.11274 & 3.12721 \\
& FEMALE, urban, Town & 182.9200 & 50 & & \\
Pair 6 & FEMALE, rural, & 174.9000 & 50 & 18.70529 & 2.64533 \\
& Bamunari & & & \\
\hline
\end{tabular}


TABLE-2

Paired Samples Correlations

\begin{tabular}{|c|c|c|c|c|}
\hline & & $\mathrm{N}$ & Correlation & Sig. \\
\hline Pair 1 & $\begin{array}{l}\text { MALE, urban \& rural \& } \\
\text { FEMALE, urban \& rural }\end{array}$ & 100 & .065 & .521 \\
\hline Pair 2 & $\begin{array}{l}\text { Urban Male \& Female \& } \\
\text { Rural Male \& Female }\end{array}$ & 100 & .003 & .979 \\
\hline Pair 3 & $\begin{array}{l}\text { MALE, urban, UGHS \& } \\
\text { FEMALE, urban, Town }\end{array}$ & 50 & .038 & .792 \\
\hline Pair 4 & $\begin{array}{l}\text { MALE, rural, Bamunari } \\
\text { \& FEMALE, rural, } \\
\text { Bamunari }\end{array}$ & 50 & -.001 & .994 \\
\hline Pair 5 & $\begin{array}{l}\text { MALE, urban, UGHS \& } \\
\text { MALE, rural, Bamunari } \\
\text { FEMALE, urban, Town }\end{array}$ & 50 & .038 & .791 \\
\hline Pair 6 & $\begin{array}{l}\text { \& FEMALE, rural, } \\
\text { Bamunari }\end{array}$ & 50 & -.049 & .738 \\
\hline
\end{tabular}


IRA-International Journal of Education \& Multidisciplinary Studies

TABLE-3

Paired Samples Test

\begin{tabular}{|c|c|c|c|c|c|c|c|c|c|}
\hline \multicolumn{10}{|c|}{ Paired Samples Test } \\
\hline & & \multicolumn{5}{|c|}{ Paired Differences } & \multirow[t]{3}{*}{$\mathrm{t}$} & \multirow[t]{3}{*}{$\mathrm{df}$} & \multirow[t]{3}{*}{ Sig. (2-tailed) } \\
\hline & & \multirow[t]{2}{*}{ Mean } & \multirow[t]{2}{*}{ Std. Deviation } & \multirow[t]{2}{*}{ Std. Error Mean } & \multicolumn{2}{|c|}{$\begin{array}{l}\text { 95\% Confidence Interval of the } \\
\text { Difference }\end{array}$} & & & \\
\hline & & & & & Lower & Upper & & & \\
\hline Pair 1 & $\begin{array}{l}\text { MALE, urban \& rural - } \\
\text { FEMALE, urban \& rural }\end{array}$ & 2.44000 & 30.50064 & 3.05006 & -3.61199 & 8.49199 & .800 & 99 & .426 \\
\hline Pair 2 & $\begin{array}{l}\text { Urban Male \& Female - } \\
\text { Rural Male \& Female }\end{array}$ & 9.42000 & 30.82082 & 3.08208 & 3.30448 & 15.53552 & 3.056 & 99 & .003 \\
\hline Pair 3 & $\begin{array}{l}\text { MALE, urban, UGHS - } \\
\text { FEMALE, urban, Town }\end{array}$ & 3.84000 & 32.39007 & 4.58065 & -5.36516 & 13.04516 & .838 & 49 & .406 \\
\hline Pair 4 & $\begin{array}{l}\text { MALE, rural, Bamunari - } \\
\text { FEMALE, rural, Bamunari }\end{array}$ & 1.04000 & 28.74800 & 4.06558 & -7.13009 & 9.21009 & .256 & 49 & .799 \\
\hline Pair 5 & $\begin{array}{l}\text { MALE, urban, UGHS - } \\
\text { MALE, rural, Bamunari }\end{array}$ & 10.82000 & 32.19056 & 4.55243 & 1.67154 & 19.96846 & 2.377 & 49 & .021 \\
\hline Pair 6 & $\begin{array}{l}\text { FEMALE, urban, Town - } \\
\text { FEMALE, rural, Bamunari }\end{array}$ & 8.02000 & 29.64793 & 4.19285 & -.40585 & 16.44585 & 1.913 & 49 & .062 \\
\hline
\end{tabular}

